\title{
An investigation of supercharged CAI engine with internal gas recirculation and direct gasoline injection
}

\begin{abstract}
Influence of boost pressure on combustion process and exhaust emission in controlled auto-ignition (CAI) engine was studied. The examinations were carried out using single-cylinder engine with fully variable valvetrain and gasoline direct injection. In order to achieve auto-ignition in-cylinder temperature was elevated with the use of internal gas recirculation (EGR) obtained via the negative valve overlap (NVO) technique.

Fuel dilution obtained via increase of intake pressure resulted in substantial reduction of cylinder-out nitrogen oxides emission. However application of boosting resulted in excessive advance of auto-ignition timing and increase of pressure rate rise (PRR) at higher engine loads.
\end{abstract}

Keywords: controlled auto-ignition, supercharging, load exchange, exhaust emission

\section{Badania doładowanego silnika CAI z wewnętrzną recyrkulacją spalin i bezpośrednim wtryskiem benzyny}

\begin{abstract}
W artykule przedstawiono analizę wptywu doładowania silnika o kontrolowanym samozapłonie (CAI) na przebieg procesu spalania oraz emisję toksycznych sktadników spalin. Obiektem badań byt jednocylindrowy silnik wyposażony w całkowicie zmienny uktad rozrzadu oraz bezpośredni wtrysk benzyny do cylindra. Do dostarczania energii niezbędnej do samozapłonu wykorzystano wewnętrzna recyrkulację spalin uzyskana dzięki ujemnemu współotwarciu zaworów.

Rozrzedzenie ładunku w cylindrze, uzyskane w wyniku doładowania, pozwolito na znaczne obniżenie emisji tlenków azotu. Doładowanie spowodowało jednak nadmierne wyprzedzenie samozapłonu oraz uzyskiwanie znacznych szybkości narastania ciśnienia w cylindrze przy większych obciążeniach silnika.
\end{abstract}

Słowa kluczowe: kontrolowany samozapłon, doładowanie mechaniczne, wymiana ładunku, emisja spalin

\section{Introduction}

A combustion system which utilizes controlled autoignition (CAI) of air-fuel mixture is nowadays one of the most promising solutions in the combustion engines development $[1,13]$. In-cylinder processes, which take place in a combustion chamber, are a combination of those typical of spark ignition and compression ignition engines. As a result of compression process in-cylinder temperature increases providing conditions for auto-ignition. However, in contrast to Diesel engines, air-fuel mixture is almost homogeneous. Appearance of auto-ignition in numerous places in the combustion chamber simultaneously is a characteristic feature of CAI combustion system $[8,10]$. Consequently, there is no flame front propagation, combustion has volumetric character and in-cylinder temperature can be treated as even within the combustion chamber. Volumetric and low temperature combustion allows for $99 \%$ reduction of NOX emission in comparison to spark ignition of homogeneous mixture [3]. Moreover, kinetic combustion results in fast heat release, thus thermal efficiency benefits from realization of close to ideal Otto cycle $[6,7]$

In CAI engines with spark ignition like compression ratios, high rate of internal gas recirculation reduces volumetric efficiency. Low amount of fresh air in the cylinder limits attainable CAI engine loads [11]. Application of boost for CAI engine enables expansion of high-load region if the bound results from amount of intake air [9]. Smaller amount of internally recirculated exhaust can be applied at increased

\section{Wstęp}

System spalania wykorzystujący kontrolowany samozapłon mieszanki paliwowo-powietrznej CAI (ang. controlled auto-ignition) jest jednym z bardziej obiecujących rozwiązań dla silników spalinowych $[1,13]$. Procesy zachodzące w cylindrze silnika CAI stanowią połączenie dwóch znanych systemów spalania stosowanych w silnikach o zapłonie iskrowym oraz o zapłonie samoczynnym. Pod wpływem sprężania, a w wyniku tego wzrostu temperatury w cylindrze, osiągane są warunki do samozapłonu. Jednakże w przeciwieństwie do silników o zapłonie samoczynnym, mieszanka paliwowo-powietrzna w cylindrze jest zbliżona do jednorodnej. Cechą systemu spalania CAI jest to, że samozapłon występuje $\mathrm{w}$ wielu miejscach przestrzeni roboczej jednocześnie $[8,10]$. W związku z tym nie obserwuje się zjawiska propagacji frontu płomienia, spalanie ma charakter objętościowy, a temperaturę w cylindrze można traktować jako jednorodną. Dzięki objętościowemu i niskotemperaturowemu spalaniu możliwe jest zmniejszenie emisji tlenków azotu z cylindra nawet o $99 \% \mathrm{w}$ stosunku do zapłonu iskrowego mieszanek jednorodnych [3]. Taki przebieg spalania skutkuje znacznym skróceniem procesu wywiązywania się ciepła, a realizacja niemal idealnego obiegu Otta prowadzi do wzrostu sprawności cieplnej $[6,7]$.

W silnikach CAI o stopniach sprężania typowych dla silników o zapłonie iskrowym znaczna ilość recyrkulowanych spalin nie pozwala na uzyskiwanie dużych wartości współczynnika napełnienia cylindra. Stanowi to ograni- 
intake pressure without drop of compression temperature. Boost pressure can also be applied in order to control amount of internal exhaust gas recirculation (EGR) without the necessity of valves timings variation [2]. Another limitation of an engine high load limit is engine noise and harshness. Increase of fuel amount at short combustion duration results in dramatic increase of heat release rate (HRR). According to Gaynor et al. [2] and Yap et al. [14] application of boost and increase of in cylinder charge mass allows substantial reduction of $\mathrm{NO}_{x}$ emission and pressure rate rise (PRR) simultaneously. In contrast, Scaringe, Wildman an Cheng $[9,12]$ reported that in order to reduce PRR intake pressure should be minimized.

The aim of this study was estimation of influence of boost pressure on CAI engine working processes. In order to achieve auto-ignition in-cylinder temperature was elevated with the use of internal EGR obtained via the negative valve overlap (NVO) technique. Research engine was fueled with gasoline with the use of direct injection. Fuel was applied into the cylinder during exhaust compression in the NVO period in order to achieve its reforming . An analysis of boost application and its impact on in-cylinder charge exchange and start of compression temperature was supported by modeling.

\section{Experimental apparatus}

Single-cylinder research engine (Table 1) was mounted on a test bed equipped with DC current dynamometer. Engine ancillaries e.g. cooling liquid pump and oil pump were driven by external electrical engines. The engine was equipped with fully variable valvetrain with independent regulation of valves lifts and timings. Regulation of valves lifts was achieved with the use of hydraulic mechanism extensively described in previous studies $[3,4,5]$. Applied valvetrain allowed the authors to obtain internal EGR via the NVO technique.

Fuel was applied into the cylinder with the use of single-stream swirl-type injector with fuel stream angle of approximately $70^{\circ}$. Injector was inclined by $38^{\circ}$ in relation

Table 1. Technical specifications of the SB 3.5 research engine

Tabela 1. Dane techniczne jednocylindrowego silnika badawczego SB 3.5

\begin{tabular}{|l|c|}
\hline Displacement/objętość skokowa & $498.5 \mathrm{~cm} 3$ \\
\hline Bore/średnica cylindra & $84 \mathrm{~mm}$ \\
\hline Stroke/skok ttoka & $90 \mathrm{~mm}$ \\
\hline Compression ratio/stopién sprężania & 11.7 \\
\hline No of valves/liczba zaworów & 2 \\
\hline Intake cam profile/profil krzywki zaworu dolotowego & $9.4 \mathrm{~mm}, 235^{\circ} \mathrm{CA} / 9,4 \mathrm{~mm}, 235^{\circ}$ OWK \\
\hline Exhaust cam profile/profil krzywki zaworu wylotowego & $9.2 \mathrm{~mm}, 235^{\circ} \mathrm{CA} / 9,2 \mathrm{~mm}, 235^{\circ}$ OWK \\
\hline Intake valve lift/wznios zaworu dolotowego & $2.4 \ldots 9.4 \mathrm{~mm}$ \\
\hline Exhaust valve lift/wznios zaworu wylotowego & $2.2 . .9 .2 \mathrm{~mm}$ \\
\hline Boost system/system doładowania & $\begin{array}{c}\text { Electrically driven vane supercharger/ } \\
\text { sprężarka łopatkowa napedzana elektrycznie }\end{array}$ \\
\hline Fuel injector/wtryskiwacz paliwa & $\begin{array}{c}\text { Solenoid actuated swirl type/elektromagnety- } \\
\text { czny generujacy zawirowanie }\end{array}$ \\
\hline Fuel pressure/ciśnienie paliwa & $40 \ldots 110$ bar \\
\hline Fuel/paliwo & Gasoline 95 RON/benzyna LOB 95 \\
\hline
\end{tabular}

czenie obciążenia silnika podczas pracy w trybie CAI [11]. Doładowanie silnika pozwala na rozszerzenie zakresu obciążenia, jeżeli ograniczenie wynika z ilości powietrza, jaka napływa do cylindra [9]. Zwiększenie ciśnienia w układzie dolotowym umożliwia stosowanie mniejszych wartości współczynnika recyrkulacji spalin przy zachowaniu odpowiedniego przebiegu krzywej sprężania. Za pomocą ciśnienia doładowania można także wpływać na ilość spalin w cylindrze bez konieczności stosowania zmian faz rozrządu [2]. Ograniczenie górnego zakresu obciążenia silnika wynika także z dopuszczalnej twardości pracy silnika. Zwiększanie dawki paliwa przy niewielkich kątach trwania procesu spalania (rzędu kilku stopni obrotu wału korbowego) wiąże się ze wzrostem szybkości narastania ciśnienia w cylindrze. Według Gaynora i in. [2] oraz Yapa i in. [14] rozrzedzenie ładunku w cylindrze przez zwiększenie ciśnienia dolotu umożliwia osiągnięcie znacznej redukcji emisji tlenków azotu i jednoczesne zmniejszenie szybkości narastania ciśnienia. Scaringe, Wildman i Cheng [9, 12] stwierdzili natomiast, że aby zredukować twardość pracy silnika, należy minimalizować ciśnienie doładowania.

Celem niniejszej pracy było określenie wpływu ciśnienia doładowania na proces roboczy silnika CAI. Do podniesienia energii wewnętrznej ładunku w cylindrze wykorzystano wewnętrzną recyrkulację spalin uzyskaną dzięki ujemnemu współotwarciu zaworów (UWZ). Silnik badawczy był zasilany benzyną za pomocą wtrysku bezpośrednio do cylindra. Wtrysk paliwa odbywał się podczas sprężania spalin, aby umożliwić reformowanie paliwa. Analiza wpływu ciśnienia początku sprężania została także przeprowadzona z wykorzystaniem modelowania.

\section{Stanowisko badaweze}

Jednocylindrowy silnik badawczy (tab. 1) zainstalowano na stanowisku dynamometrycznym wyposażonym w maszynę prądu stałego. Elementy osprzętu silnika, takie jak pompa cieczy chłodzącej oraz pompa oleju, napędzane były przez zewnętrzne urządzenia. Silnik został wyposażony w mechanizm niezależnej regulacji faz rozrządu oraz wzniosu zaworów. Zmianę wzniosu zaworów uzyskano za pomocą mechanizmu hydraulicznego szczegółowo opisanego w pracach [3, 4, 5]. Zastosowany układ rozrządu umożliwił uzyskanie wewnętrznej recyrkulacji spalin z wykorzystaniem ujemnego współotwarcia zaworów.

Paliwo podawane było bezpośrednio do cylindra za pomoca wtryskiwacza jednostrumieniowego wirowego o kącie stożka strugi paliwa wynoszącym około $70^{\circ}$. Wtryskiwacz umieszczony został w głowicy silnika pod kątem $38^{\circ}$ do osi cylindra oraz stycznie do doładowania na przebieg procesu dolotu oraz temperaturę 
to the cylinder axis tangentially to the swirl generated by the shape of the intake port.

As the boost device a vane compressor was used which was driven by electric motor. Intake pressure was controlled via compressor rotational speed.

The composition of exhaust gases was measured with the FTIR multi-compound gas analytical system. The mass of trapped residuals was calculated using the Ideal Gas Equation of State based on the in-cylinder pressure, volume above the piston and calculated temperature at exhaust valve closing (EVC). The gas constant was calculated on the base of the measured exhaust gas composition. Fuel consumption was measured via a fuel balance.

Indicated pressure was measured using piezoelectric transducer type GH 12D from AVL cooperating with charge amplifier from the same manufacturer. At each engine operation point pressure was recorded for 100 consecutive cycles with constant crank angle resolution equal $0.1^{\circ} \mathrm{CA}$.

\section{Experimental conditions and procedure}

The examinations were carried out at constant rotational speed equal $1500 \mathrm{rev} / \mathrm{min}$ and wide open throttle. The engine was fuelled with gasoline (95 RON) from a single batch. Fuel pressure measured in a fuel rail was equal $10 \mathrm{MPa}$. Valves lifts were reduced to $3.6 \mathrm{~mm}$ for inlet valve and $2.9 \mathrm{~mm}$ for exhaust valve in order to realize NVO. Valves timings were constant and specified in Table 2.

Table 2. Valvetrain settings

Tabela 2. Ustawienia układu rozrządu

\begin{tabular}{|c|c|c|c|}
\hline \multicolumn{5}{|c|}{ Valves timings $\left[{ }^{\circ} \mathrm{CA}\right] /$ fazy rozrządu $\left[{ }^{\circ} \mathrm{OWK}\right]$} \\
\hline $\mathrm{IVO} / \mathrm{OD}$ & 85 & $\mathrm{EVO} / \mathrm{OW}$ & 516 \\
\hline $\mathrm{IVC} / \mathrm{ZD}$ & 210 & $\mathrm{EVC} / \mathrm{ZW}$ & 635 \\
\hline \multicolumn{4}{|c|}{ Valves lifts $[\mathrm{mm}] /$ wzniosy zaworów $[\mathrm{mm}]$} \\
\hline Intake/dolotowy & 3.6 & Exhaust/wylotowy & 2.9 \\
\hline
\end{tabular}

The intake pressure at each measurement series was varied form atmospheric level to $0.15 \mathrm{MPa}$ at set fuel dose. At the largest fuel dose minimal intake pressure was elevated in order to avoid rich mixture combustion. Fuel was injected into the cylinder during exhaust compression $40^{\circ} \mathrm{CA}$ before top dead center in the NVO period. Such injection timing allowed in-cylinder fuel reforming which enabled combustion of extremely lean mixtures. The experiments were conducted at three fuel doses equal $9.5,13$ and $16.3 \mathrm{mg}$. Indicated mean effective pressure (IMEP) at variable intake pressure was kept at almost constant level for each fuel dose and was equal $0.23,0.34$ and $0.42 \mathrm{MPa}$ respectively.

The results analysis was based on the measured indicated pressure. The values which characterized combustion process in crank angle domain were derived from HRR curves calculated using the first thermodynamic law. On the basis of cumulated heat released in the combustion chamber, mass fraction burnt (MFB) was estimated. PRR was calculated as a slope of a straight line approximation of pressure curve from $20 \%$ to $80 \%$ MFB. As mechanical supercharging was used in this study, energy demand for the compressor driv- kierunku zawirowania ładunku wywołanego przez kształt kanału dolotowego.

Do zwiększenia ciśnienia w układzie dolotowym zastosowano sprężarkę łopatkową napędzaną przez silnik elektryczny. Wartość ciśnienia dolotu utrzymywana była przez zmianę prędkości obrotowej silnika napędowego.

Skład spalin mierzony był za pomocą wieloskładnikowego systemu analitycznego typu FTIR. Masa spalin recyrkulowanych znajdujących się w cylindrze wyznaczana była na podstawie równania stanu gazu, opierając się na ciśnieniu w cylindrze, objętości nad tłokiem oraz obliczonej temperaturze czynnika roboczego w chwili zamknięcia zaworu wylotowego. Wartość stałej gazowej obliczano na podstawie składu spalin. Zużycie paliwa mierzono metodą grawimetryczną.

Do pomiaru ciśnienia indykowanego w cylindrze wykorzystano piezoeketryczny przetwornik typu GH 12D produkcji firmy AVL współpracujący ze wzmacniaczem ładunku tego samego producenta. W każdym punkcie pracy silnika ciśnienie było rejestrowane dla 100 kolejnych cykli roboczych ze stałą rozdzielczością kątową $0,1^{\circ} \mathrm{OWK}$.

\section{Warunki badań i analiza wyników}

Badania przeprowadzono przy stałej prędkości obrotowej silnika wynoszącej $1500 \mathrm{obr} / \mathrm{min}$ i całkowitym otwarciu przepustnicy. Silnik był zasilany benzyną o badawczej liczbie oktanowej 95, pochodzącą z jednej dostawy. Ciśnienie paliwa przed wtryskiwaczem wynosiło $10 \mathrm{MPa}$. Aby zrealizować UWZ, wzniosy zaworów zostały zredukowane i wynosiły odpowiednio 3,6 mm dla zaworu dolotowego oraz 2,9 mm dla zaworu wylotowego. Fazy rozrządu były stałe (tab. 2).

Ciśnienie w układzie dolotowym w każdej serii pomiarowej zmieniano od atmosferycznego do 0,15 MPa przy ustalonej dawce paliwa. Dla największej dawki paliwa minimalne ciśnienie w układzie dolotowym podyktowane było wartością współczynnika nadmiaru powietrza, aby silnik nie pracował przy mieszance bogatej. Paliwo podawane było do cylindra w czasie sprężania spalin $40^{\circ} \mathrm{OWK}$ przed górnym zwrotnym położeniem tłoka w okresie UWZ. Dzięki temu uzyskano reformowanie paliwa w cylindrze i możliwe było stosowanie mieszanek bardzo ubogich. Badania przeprowadzono dla trzech wartości dawki paliwa wynoszących 9,5, 13 oraz 16,3 mg. Średnie ciśnienie indykowane przy stałej dawce paliwa nie ulegało zmianom w zależności od ciśnienia doładowania i wynosiło odpowiednio $0,23,0,34$ oraz $0,42 \mathrm{MPa}$.

Analizę wyników badań oparto na pomiarach ciśnienia indykowanego w cylindrze. Wielkości charakteryzujące kątowy przebieg spalania obliczane były na podstawie krzywych szybkości wywiązywania się ciepła w cylindrze (HRR) wyznaczanych z wykorzystaniem I zasady termodynamiki. Na podstawie skumulowanego ciepła wywiązanego w komorze spalania obliczano stopień wypalenia dawki paliwa. Szybkość przyrostu ciśnienia w cylindrze (PRR) obliczano jako współczynnik kierunkowy liniowej aproksymacji krzywej ciśnienia w zakresie od $20 \%$ do $80 \%$ wypalenia dawki paliwa. Przy zastosowaniu doładowania mechanicznego nie 
ing was not considered. The adiabatic compression work for building-up intake pressure up to $0.15 \mathrm{MPa}$ would decrease the engine thermal efficiency in the range from $7 \%$ to $10 \%$ in accordance to fuel dose injected.

\section{Experimental results}

\subsection{Combustion course}

Increase of intake pressure at constant fuel dose resulted in auto-ignition timing advance and substantial rise of maximum pressure (Fig. 1). The presented influence of boost pressure is in contrast to results obtained by Gaynor et al. [2] and Yap et al. [14], who observed that fuel dilution resulting for boost application delays auto-ignition and decreases combustion harshness. However, it should be noticed that mentioned authors did not apply fuel reforming. If fuel is injected during the NVO period, increase of air excess ratio and oxygen content in the exhaust gases is in favor of reforming process and results in auto-ignition advance [3].
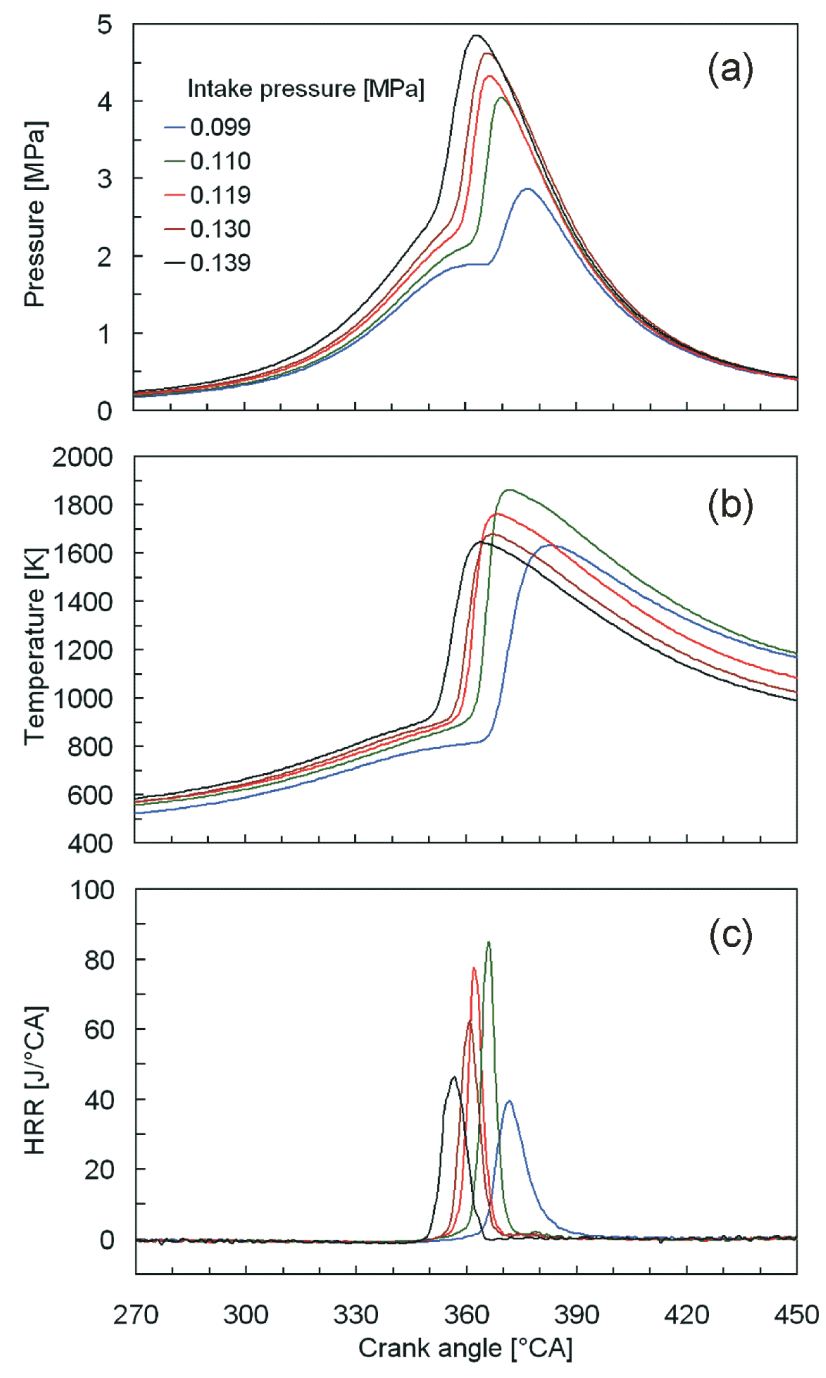

Fig. 1. In-cylinder pressure (a), temperature (b) and apparent heat release rate (c) at variable intake pressure; fuel dose $13 \mathrm{mg}$, $\mathrm{IMEP}=0.34 \mathrm{MPa}$

Rys. 1. Ciśnienie w cylindrze (a), temperatura (b) oraz szybkość wywiazywania się ciepta (c) przy zmiennym ciśnieniu w uktadzie dolotowym; dawka paliwa $13 \mathrm{mg}, p_{i}=0,34 \mathrm{MPa}$ uwzględniono energii potrzebnej do napędu sprężarki. Praca adiabatycznego sprężania powietrza w układzie dolotowym silnika, przy ciśnieniu doładowania $0,15 \mathrm{MPa}$, obniżałaby sprawność cieplną silnika od 7\% do $10 \%$, zależnie od dawki paliwa.

\section{Wyniki badań}

\subsection{Przebieg spalania}

Zwiększenie ciśnienia doładowania przy stałej dawce paliwa powoduje wyprzedzenie kąta samozapłonu oraz znaczący wzrost maksymalnych wartości ciśnienia w cylindrze (rys. 1). Takie zmiany przebiegu spalania są sprzeczne z wynikami uzyskanymi przez Gaynora i in. [2] oraz Yapa i in. [14], którzy zaobserwowali, że wzrost ciśnienia doładowania $\mathrm{i}$ wynikające $\mathrm{z}$ tego rozrzedzenie ładunku opóźniają samozapłon i obniżają twardość pracy silnika. Należy jednak pamiętać, że wspomniani autorzy nie wykorzystywali reformowania paliwa w cylindrze. W odniesieniu do wtrysku bezpośrednio do komory spalania w czasie UWZ, zubażanie mieszanki na skutek doładowania intensyfikuje proces reformowania paliwa w cylindrze, co powoduje wyprzedzanie samozapłonu [3].

Efekt ten może być także zaobserwowany na podstawie porównania przebiegów procesu spalania przy różnych dawkach paliwa i stałym ciśnieniu doładowania. Dla najmniejszej dawki paliwa uzyskano najwcześniejszy zapłon (rys. 2). Takie zachowanie jest skutkiem wpływu ilości tlenu w spalinach na stopień reformowania paliwa. Zwiększanie dawki paliwa powoduje obniżenie zawartości tlenu w spalinach oraz wzrost stosunku masowego paliwa do tlenu w czasie ujemnego współotwarcia zaworów. Jednakże dla dwóch większych wartości obciążenia kąt samozapłonu był na podobnym poziomie. W tym przypadku zmniejszanie nadmiaru powierza, powodujące wyprzedzanie samozapłonu, kompensowało wpływ procesu reformowania.

W zakresie mniejszych ciśnień wraz ze wzrostem ciśnienia doładowania ulega także skróceniu kąt spalania, a w związku z tym jeszcze bardziej wzrasta twardość pracy silnika. Przy dalszym zwiększaniu ciśnienia doładowania maksymalna szybkość wywiązywania się ciepła nieznacznie maleje (rys. 3), co może być związane ze wzrostem współczynnika nadmiaru powietrza $\lambda$.

Największe wartości szybkości wywiązywania się ciepła zaobserwowano, jeżeli 50\% wypalenia dawki paliwa przypadało na górne zwrotne położenie tłoka. Przy większych dawkach paliwa wyprzedzanie samozapłonu na skutek zwiększania ciśnienia w układzie dolotowym powodowało znaczący wzrost szybkości narastania ciśnienia (rys. 3c). Pomimo opóźnienia wywiązywania się ciepła, następował wzrost twardości pracy silnika, co było związane z większą ilością energii dostarczonej do cylindra oraz skróceniem kąta spalania. Przy ciśnieniu doładowania 0,13 MPa i dawce paliwa wynoszącej $13 \mathrm{mg}$ kąt wypalenia od 5\% do 95\% dawki paliwa wynosił $6,5^{\circ} \mathrm{OWK}$, natomiast dla większej dawki (16,3 mg) kąt ten wynosił $4{ }^{\circ}$ OWK. Spowodowało to wzrost szybkości wywiązywania się ciepła większy, niż wynikałoby to z samej dawki paliwa oraz dwukrotny wzrost 

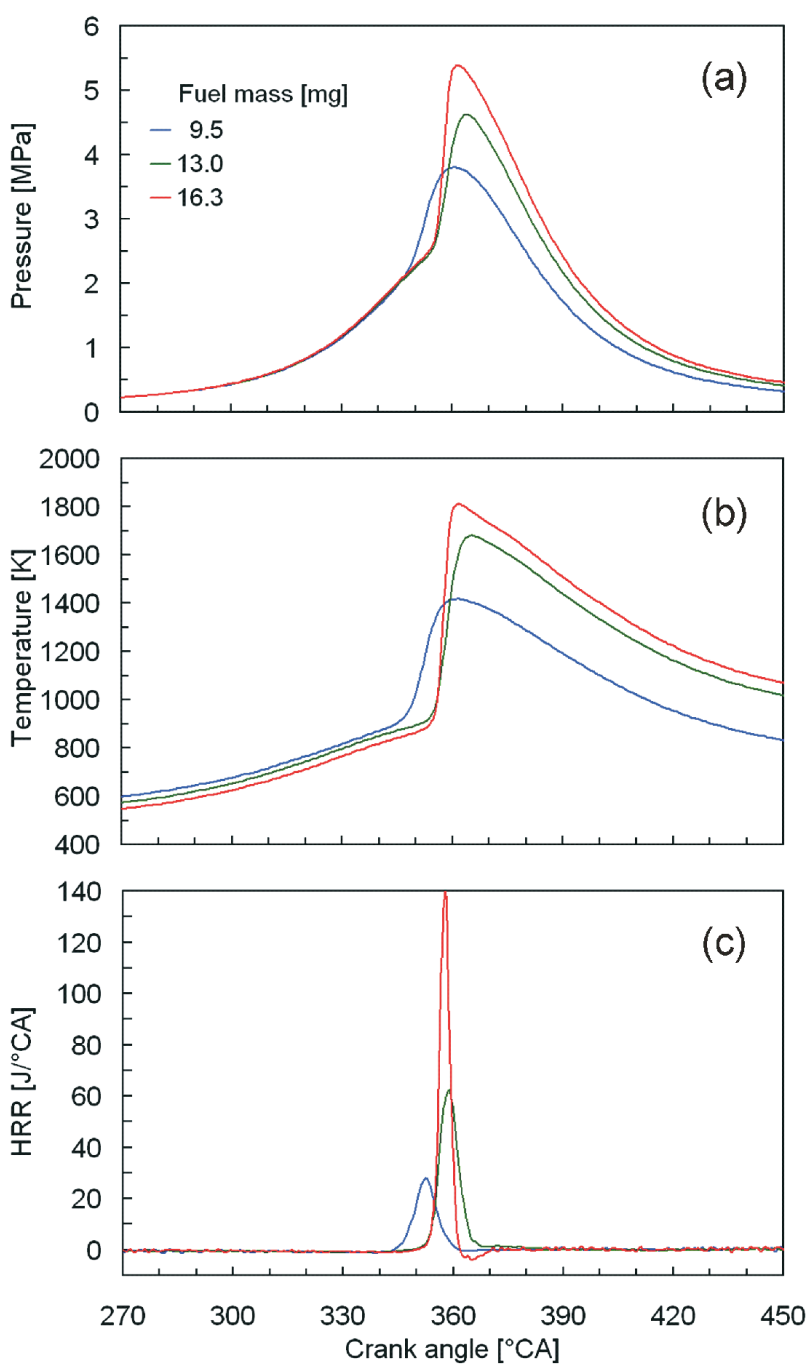

Fig. 2. In-cylinder pressure (a), temperature (b) and apparent heat release rate (c) at variable fuel dose; intake pressure $0.13 \mathrm{MPa}$

Rys. 2. Ciśnienie w cylindrze (a), temperatura (b) oraz szybkość wywiazywania się ciepła (c) przy zmiennej dawce paliwa; ciśnienie w układzie dolotowym 0,13 $\mathrm{MPa}$

This effect can also be seen on the basis of combustion courses comparison for different fuel doses and constant intake pressure. At the lowest analyzed engine load the earliest auto-ignition was observed (Fig. 2). It was an effect of fuel reforming degree due to oxygen excess in the exhaust gases. Increase of fuel dose resulted in decrease of oxygen excess and higher fuel to exhaust mass ratio during the NVO period. However, for two larger fuel amounts the auto-ignition timing was at similar level. In this case, decrease of air excess, resulting in auto-ignition advance, compensated impact of reforming process.

In the range of lower intake pressure, its increase resulted in reduction of combustion duration, what additionally influenced HRR and PRR. HRR dropped at higher intake pressures (Fig. 3), what could be ascribed to increase of air excess ratio $\lambda$.

Maximum values of HRR were observed when $50 \%$ of MFB took place at piston top dead center. At larger fuel doses auto-ignition advance at rising intake pressure resulted
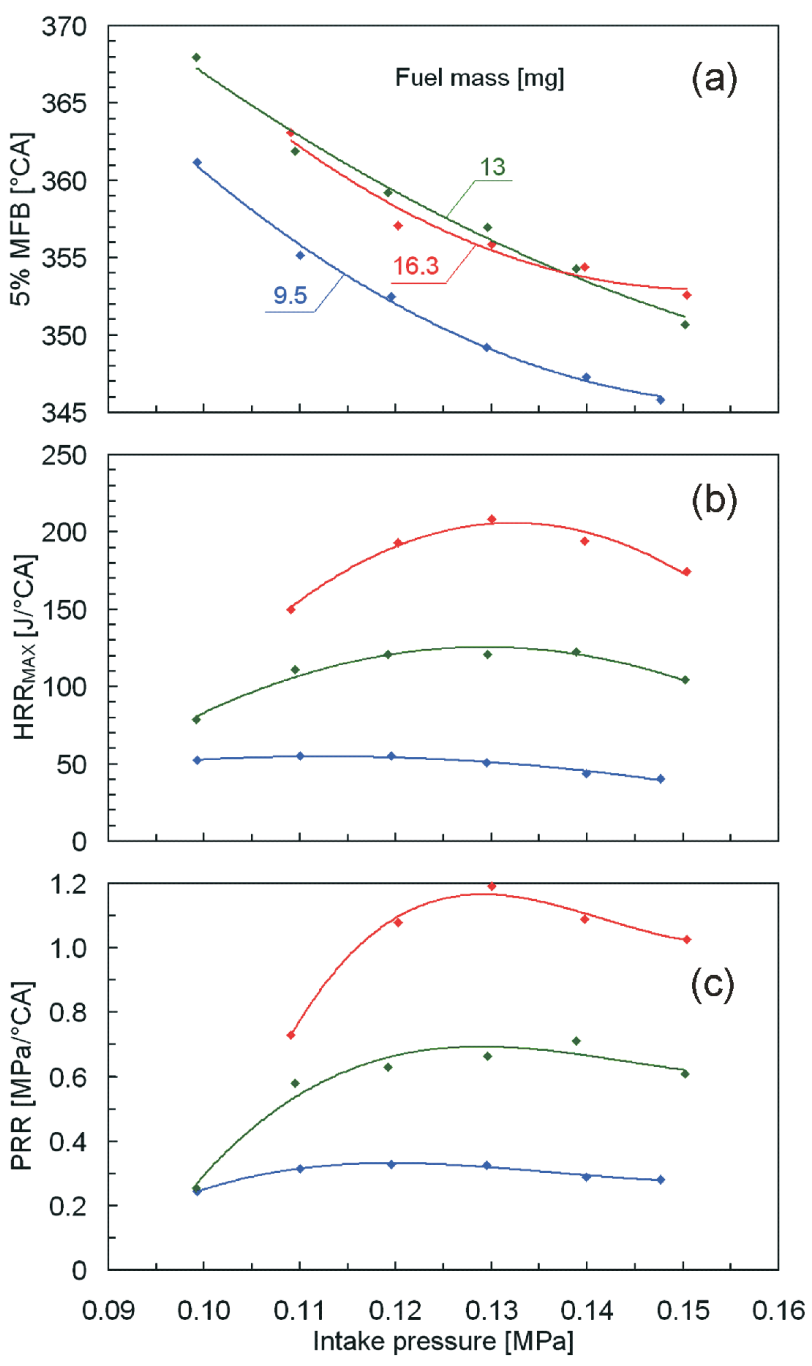

Fig. 3. Crank angle $5 \%$ of mass fraction burnt (a), maximum heat release rate (b) and pressure rise rate (c) with respect to intake pressure at different engine loads

Rys. 3. Polożenie watu korbowego przy 5-procentowym wypaleniu dawki paliwa (a), maksymalna szybkość wywiązywania się ciepła (b) oraz szybkość narastania ciśnienia (c) w funkcji ciśnienia w układzie dolotowym dla zmiennego obciążenia silnika

szybkości narastania ciśnienia. W zakresie najmniejszego obciążenia silnika ciśnienie doładowania nie wywoływało zmian szybkości narastania ciśnienia, ponieważ znaczne wyprzedzenie samozapłonu powodowało, że proces spalania kończył się jeszcze przed GMP.

\subsection{Wymiana ladunku}

Na podstawie wyników badań eksperymentalnych stwierdzono, że wzrost ciśnienia w układzie dolotowym poza zwiększeniem napełnienia cylindra świeżym powietrzem powoduje także obniżenie współczynnika recyrkulacji spalin, lecz tylko dla małej dawki paliwa (rys. 4). Przy większych dawkach paliwa zmiany współczynnika recyrkulacji spalin nie są monotoniczne. W zakresie małych ciśnień doładowania wzrost ciśnienia powoduje zwiększenie napełnienia względem reszty spalin, natomiast w zakresie większych ciśnień dominującą rolę odgrywa wzrost gęstości spalin 
in substantial increase of PRR (Fig. 3c). At larger fuel doses this effect was reduced in some extent via start of combustion delay. Nevertheless, increase of energy provided into the cylinder with fuel resulted in excessive rise of combustion harshness. Also, combustion duration plays important role in PRR behavior. At intake pressure equal $0.13 \mathrm{MPa}$ and fuel mass equal $13 \mathrm{mg}$ combustion duration, calculated from $5 \%$ to $95 \%$ of MFB, took $6.5{ }^{\circ} \mathrm{CA}$, while at larger fuel dose $(16,3) \mathrm{mg}$ combustion was shortened to $4{ }^{\circ} \mathrm{CA}$. Combination of both effects provided the HRR increase bigger than one resulting from the fuel dose only. At the lowest engine load early auto-ignition resulted with combustion termination prior to TDC. Thus, in this case increase of intake pressure did not influence PRR in a high extend.

\subsection{Charge exchange}

Experimental measurements and calculations showed that increase of intake pressure, apart from increase of fresh air in the cylinder, reduces the EGR rate, however only for small fuel dose (Fig. 4). For two larger fuel doses changes of EGR rate are not monotonous. In the range of light boost increase of intake pressure results with drop of mass of trapped residuals. However, at higher boost pressures dominant role play drop of exhaust temperature and increasing flow resistance through the exhaust valve. Considering changes in values of fresh air mass, exhaust mass and exhaust temperature, it should be expected that boost application will result in drop of compression temperature. However, experimental results provided relationship opposite to expected one.

In order to analyze phenomena which take place during the intake process modeling study with the use of AST Boost software from AVL was performed. Calculations were done at the same conditions as during experiments and for fuel dose equal $13 \mathrm{mg}$. During model validation, its parameters were set in order to obtain in-cylinder mass and pressure traces similar to experimental ones.

Figure 5 presents measured and calculated in-cylinder pressure traces. The curves of HRR were introduced into the model on the base of the thermodynamic experimental data analysis. At atmospheric intake pressure (Fig. 5a) satisfactory fit of the measured pressure with the model results was obtained. However, at intake pressure equal $0.15 \mathrm{MPa}$ calculated data provided lower expansion pressure values during the NVO period. It was a result of heat release during NVO.

Figure 6a presents in-cylinder mass during intake process. Values calculated from experimental measurements at IVO and IVC were presented as well. In the range of higher boost pressures, increase of intake pressure and resulting fuel dilution ratio causes increase of the mass of trapped residuals. Such behavior is comprehensible, as density of the exhaust gases is rising too. However, both modeling and experimental studies provided results showing that at atmospheric intake pressure the mass of trapped residuals is higher than at light boost.

The results of calculations confirmed relationship between intake pressure and compression temperature observed on the base of experimental data. At increasing amount of fresh air temperature at IVO is dropping, while temperature
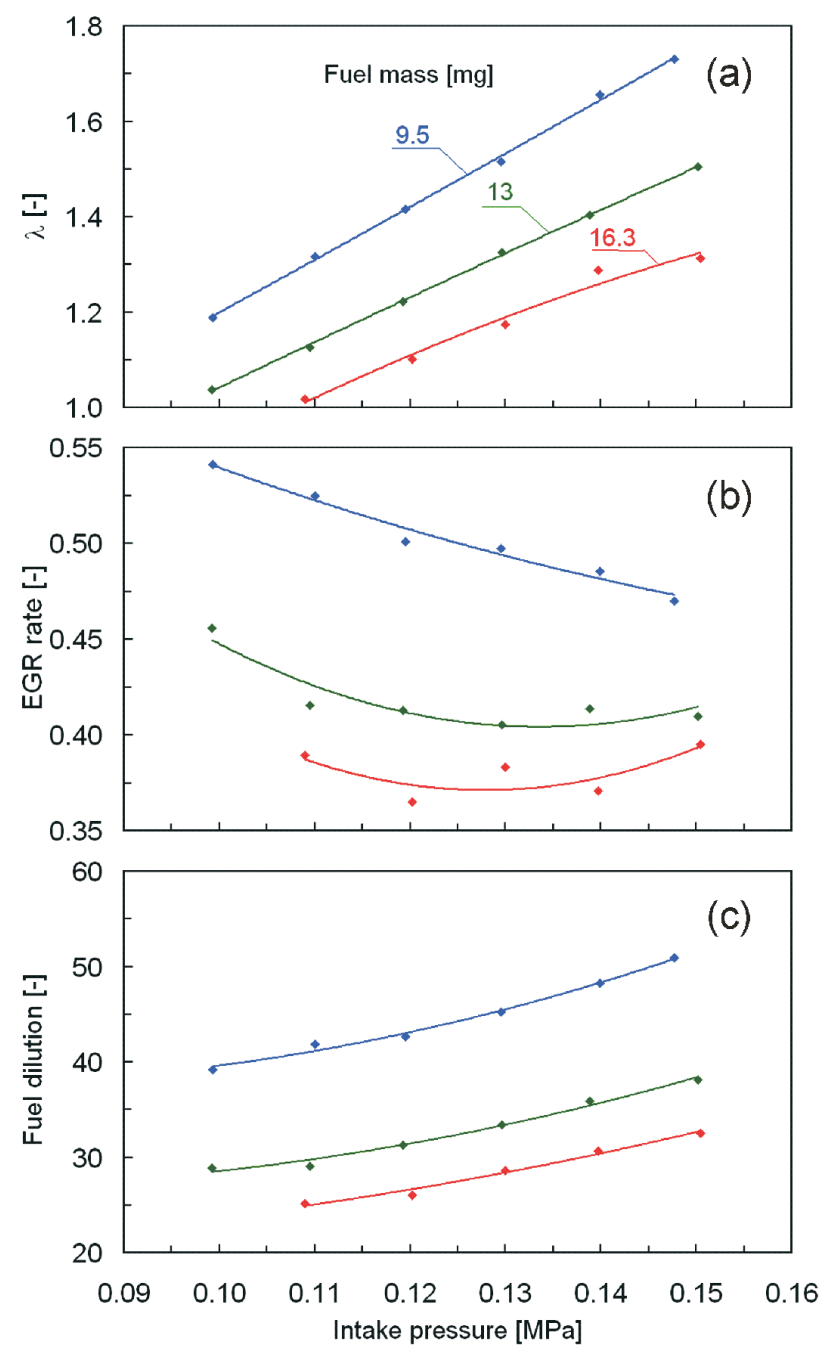

Fig. 4. Air excess ratio (a), EGR rate (b) and fuel dilution ratio (c) with respect to intake pressure at different engine loads

Rys. 4. Współczynnik nadmiaru powietrza (a), współczynnik recyrkulacji spalin (b) oraz stopień rozrzedzenia ładunku (c) w funkcji ciśnienia w uktadzie dolotowym dla zmiennego obciązenia silnika

wynikający z obniżenia temperatury oraz opory przepływu przez zawór wylotowy. Biorąc pod uwagę zmiany ilości powietrza i spalin oraz ich temperatury, należałoby oczekiwać, że doładowanie spowoduje obniżenie temperatury sprężania. Wyniki eksperymentów dostarczyły jednak rezultatów odwrotnych do spodziewanych.

Aby rozpoznać zjawiska zachodzące podczas procesu dolotu, przeprowadzono badania symulacyjne z wykorzystaniem oprogramowania komputerowego AST Boost firmy AVL. Obliczenia wykonano dla warunków pracy silnika takich samych jak podczas badań eksperymentalnych oraz dawki paliwa wynoszącej $13 \mathrm{mg}$. Podczas walidacji parametry modelu dobrano tak, aby uzyskać masę powietrza w cylindrze odpowiadającą wynikom badań eksperymentalnych oraz zbliżony przebieg ciśnienia w cylindrze.

Na rysunku 5 przedstawiono przebiegi ciśnienia w cylindrze pochodzące $\mathrm{z}$ pomiarów oraz wyniki modelowania dla dwóch wartości ciśnienia doładowania. Krzywą szybkości wywiązywania się ciepła wprowadzono do modelu na 
at IVC is rising (Fig. 6c). These temperature changes result from compression of the mixture during intake process. Pressure at the IVO event was lower than ambient pressure for all applied boost pressures (Fig. 6b). As a result there was no temperature drop during intake resulting from pressure drop as it was observed for lower intake pressure values.

\subsection{Exhaust emission}

At elevated intake boost pressure emission of nitrogen oxides considerably decreased, apart from increase of peak in-cylinder pressure. In the case of $0.34 \mathrm{MPa}$ IMEP (fuel dose equal $13 \mathrm{mg}$ ) increase of intake pressure from atmospheric to $0.15 \mathrm{MPa}$ enabled for reduction of cylinder-out $\mathrm{NO}_{\mathrm{x}}$ emission from 1.4 to $0.2 \mathrm{~g} /(\mathrm{kW} \cdot \mathrm{h})$ (Fig. 7), what meant molar fraction of about $30 \mathrm{ppm}$. At the lowest analyzed engine load and maximum boost pressure the molar fraction of $\mathrm{NO}_{\mathrm{x}}$ was equal $4 \mathrm{ppm}$ and resulting emission was $0.04 \mathrm{~g} /(\mathrm{kW} \cdot \mathrm{h})$. In should be noted that at low loads mechanical charger energy demand in comparison to cycle indicated work is higher and high boost results in rise of fuel consumption.
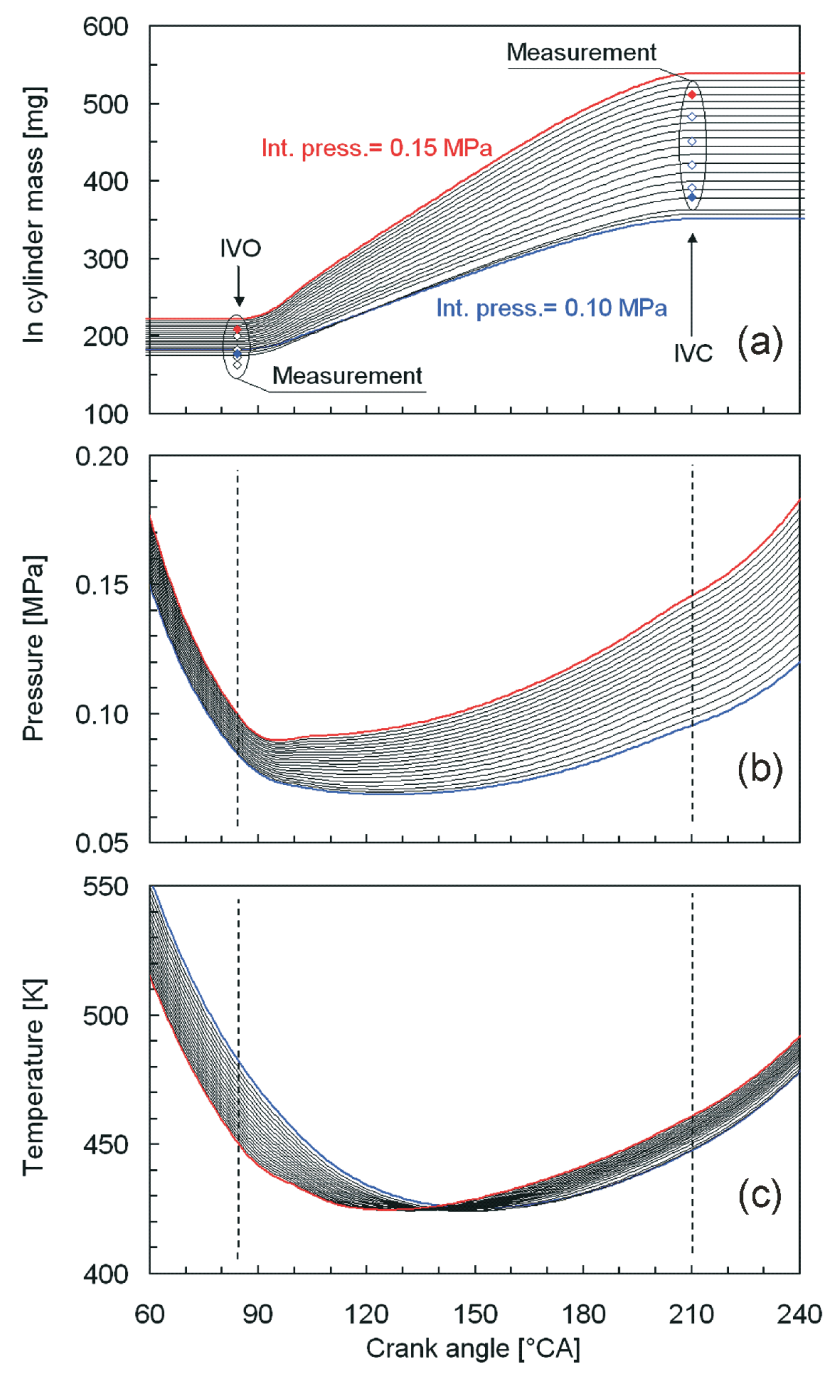

Fig. 6. Calculated in-cylinder mass (a), pressure (b) and temperature (c) during intake process

Rys. 6. Obliczona masa w cylindrze (a), ciśnienie (b) oraz temperatura (c) $w$ czasie procesu dolotu
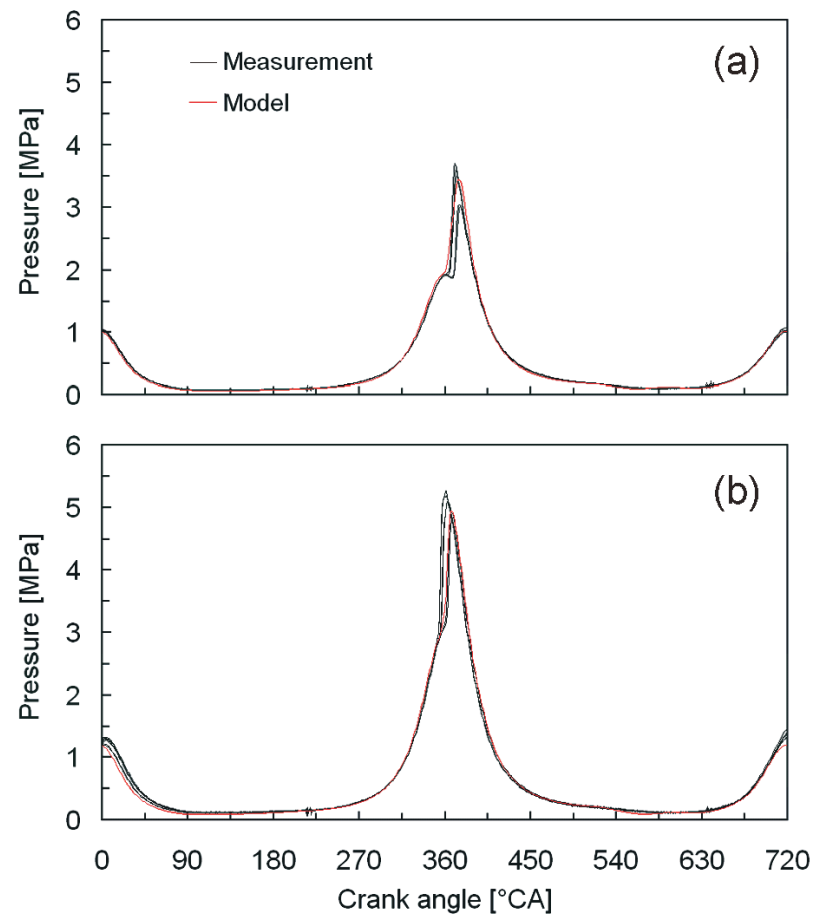

Fig. 5. In-cylinder pressure measured for several cycles and calculated with the use of the model at $13 \mathrm{mg}$ of fuel; a) engine naturally aspirated, b) intake pressure equal $0,15 \mathrm{MPa}$

Rys. 5. Ciśnienie w cylindrze zmierzone dla kilku cykli oraz obliczone $z$ wykorzystaniem modelu przy dawce paliwa wynoszacej $13 \mathrm{mg}$; a) silnik wolnossacy, b) ciśnienie w układzie dolotowym wynoszace 0,15 MPa

podstawie analizy termodynamicznej ciśnienia w cylindrze. Przy atmosferycznym ciśnieniu dolotu (rys. 5a) uzyskano zadowalającą zgodność symulacji z pomiarami. Natomiast dla ciśnienia 0,15 MPa na podstawie modelu uzyskano nieco mniejsze wartości ciśnienia w czasie rozprężania spalin (rys. 5b). Jest to związane z wydzielaniem się niewielkich ilości ciepła w czasie UWZ.

Na rysunku 6a przedstawiono wartości masy czynnika w cylindrze w czasie procesu dolotu. Oznaczono także masę spalin zatrzymywanych w cylindrze oraz masę ładunku po zakończeniu procesu dolotu pochodzące $\mathrm{z}$ pomiarów. W zakresie większych ciśnień dolotu, przy zwiększającym się rozrzedzeniu ładunku i zmniejszającej się temperaturze spalin, wzrasta ilość spalin zatrzymywanych w cylindrze. Jest to zrozumiałe, ponieważ wzrasta także gęstość spalin. Z badań eksperymentalnych i modelowych wynika jednak, że przy atmosferycznym ciśnieniu dolotu masa spalin $\mathrm{w}$ cylindrze jest większa, niż przy niewielkich ciśnieniach doładowania.

Obliczenia potwierdziły zaobserwowaną zależność pomiędzy ciśnieniem w układzie dolotowym i temperaturą sprężania. Przy zwiększającym się napełnieniu cylindra temperatura otwarcia zaworu dolotowego zmniejsza się. Pomimo to wzrasta temperatura zamknięcia zaworu (rys. 6c), co jest skutkiem sprężania ładunku podczas procesu dolotu. Ciśnienie w chwili otwarcia zaworu dolotowego jest znacznie mniejsze niż ciśnienie w układzie dolotowym (rys. 6b). Powoduje to, że nie występuje spadek temperatury w 
Fuel dilution and resulting reduction of in-cylinder temperature caused increase in terms of $\mathrm{CO}$ emission. At the smallest fuel dose application of boost resulted in increase of $\mathrm{CO}$ emission from 7 to $9 \mathrm{~g} /(\mathrm{kW} \cdot \mathrm{h})$. However at larger fuel doses emission of $\mathrm{CO}$ was kept at almost constant level independently from boost pressure. Lack of boost influence on $\mathrm{CO}$ emission is associated with the peak in-cylinder temperature, which was changing within a limited range (Fig. 1b). For all analyzed engine loads increase of intake pressure resulted in reduction of unburned $\mathrm{HC}$ emission about $30 \%$ for the applied pressure range.

\section{Conclusions}

Results of experiments and modeling of the mechanically boosted CAI gasoline engine with direct gasoline injection were presented in this study. Earlier research proved that naturally aspirated CAI engine can be operated at loads up to $0.4 \mathrm{MPa}$ of IMEP [3]. The necessity of stoichiometric mixture application in the range of higher loads resulted
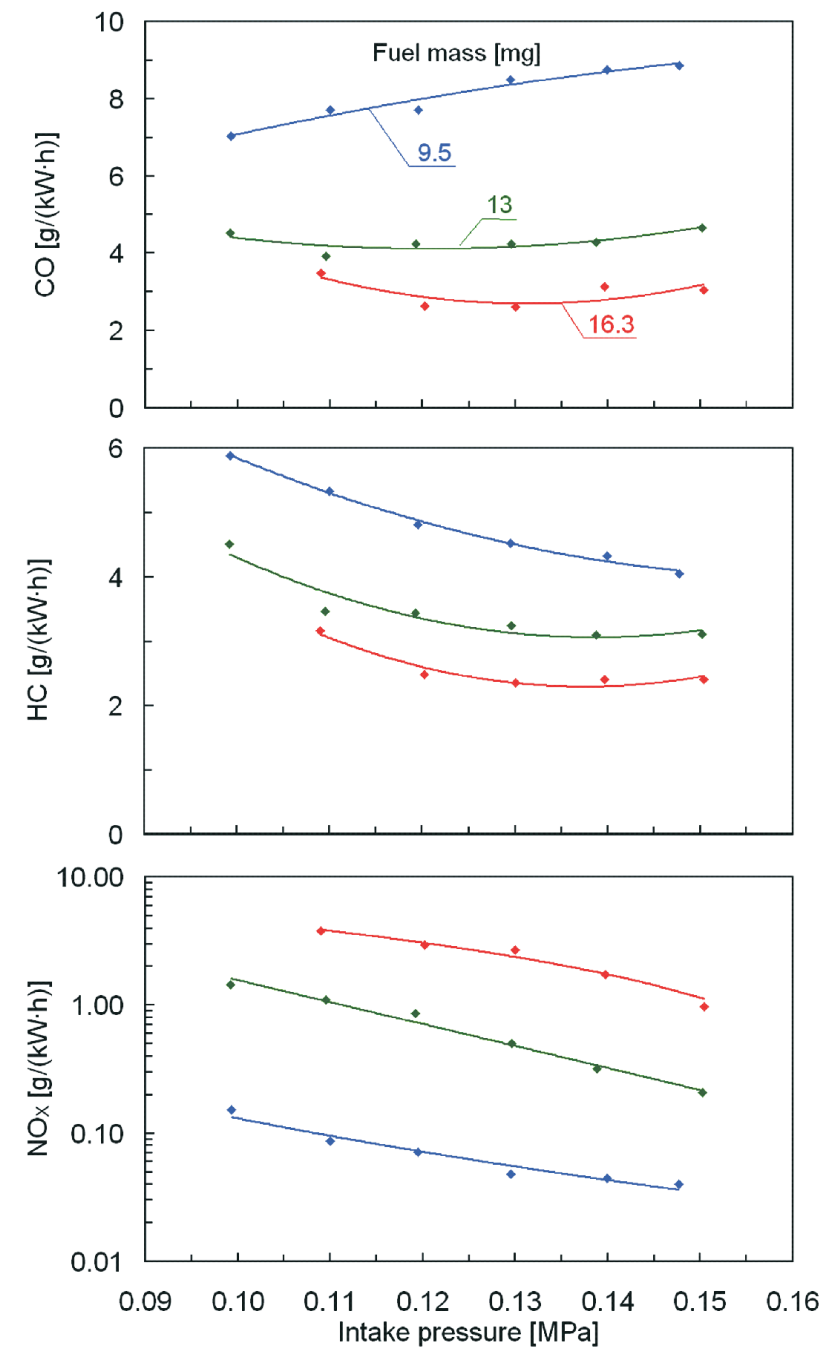

Fig. 7. Indicated specific emission of toxic compounds with respect to intake pressure at different engine loads

Rys. 7. Jednostkowa indykowana emisja toksycznych sktadników spalin w funkcji ciśnienia w układzie dolotowym dla zmiennego obciążenia silnika cylindrze na skutek rozprężania, jak przy mniejszych wartościach ciśnienia w układzie dolotowym.

\subsection{Emisja toksycznych składników spalin}

Pomimo wzrostu ciśnienia w cylindrze wraz z wartością ciśnienia doładowania emisja tlenków azotu znacząco maleje. Dla średniego ciśnienia indykowanego wynoszącego 0,34 MPa (przy dawce paliwa wynoszącej $13 \mathrm{mg}$ ) wzrost ciśnienia doładowania od ciśnienia atmosferycznego do 0,15 MPa pozwolił na zmniejszenie emisji tlenków azotu z 1,4 do 0,2 g/(kW·h) (rys. 7), co odpowiadało stężeniu molowemu około $30 \mathrm{ppm}$. Przy najmniejszym analizowanym obciążeniu silnika uzyskano stężenia molowe tlenków azotu na poziomie 4 ppm i emisję $0,04 \mathrm{~g} /(\mathrm{kW} \cdot \mathrm{h})$. Należy jednak pamiętać, że przy małych dawkach paliwa udział energii potrzebnej do napędu sprężarki w stosunku do pracy indykowanej zwiększa się, powodując wzrost zużycia paliwa.

Rozrzedzanie ładunku w cylindrze i obniżanie temperatury spalania powodują wzrost emisji tlenku węgla, jednakże tylko w zakresie małych obciążeń. Przy dawce paliwa 9,5 mg doładowanie spowodowało wzrost emisji $\mathrm{CO}$ z 7 do $9 \mathrm{~g} /(\mathrm{kW} \cdot \mathrm{h})$, natomiast przy większych obciążeniach silnika, gdzie doładowanie wiązało się ze znacznym wzrostem ciśnienia w cylindrze, emisja CO utrzymywała się na niemal stałym poziomie. Brak wpływu rozrzedzenia ładunku na emisję CO może być wytłumaczony tym, że maksymalna temperatura $\mathrm{w}$ cylindrze nie ulegała znaczącym zmianom (rys. 1b). Zwiększenie ciśnienia w układzie dolotowym od atmosferycznego do 0,15 MPa powodowało obniżenie emisji niespalonych węglowodorów o około $30 \%$ niezależnie od dawki paliwa.

\section{Podsumowanie}

W pracy przedstawiono wyniki badań doładowanego mechanicznie silnika CAI zasilanego bezpośrednim wtryskiem benzyny. Wcześniejsze badania dowiodły, że wolnossący silnik CAI może uzyskiwać maksymalne obciążenia zaledwie na poziomie $0,4 \mathrm{MPa}$ średniego ciśnienia indykowanego [3]. Konieczność tworzenia mieszanki zbliżonej do stechiometrycznej w zakresie większych obciążeń powoduje wzrost emisji tlenków azotu. Celem zastosowania doładowania w silniku z wewnętrzną recyrkulacją spalin, poza umożliwieniem poszerzenia zakresu pracy silnika, było również zmniejszenie emisji tlenków azotu.

Najważniejsze wnioski wynikające z przeprowadzonych badań można sformułować następująco:

1.Doładowanie nie wpływa w znaczącym stopniu na sprawność cieplną silnika, jednakże uwzględnienie pracy sprężania mechanicznego powoduje, że jest ono niekorzystne z energetycznego punktu widzenia. Zastosowanie turbosprężarki w silniku wielocylindrowym mogłoby rozwiązać ten problem. Spiętrzenie spalin przez turbinę byłoby kompensowane większym kątoprzekrojem zaworu wylotowego.

2.Zwiększenie ciśnienia w układzie dolotowym silnika, niezależnie od dawki wtryskiwanego paliwa, prowadzi do wzrostu szybkości narastania ciśnienia ze względu na wyprzedzenie samozapłonu. 
in excessive NOx emission. The aim of boost application, apart from possible extension of the high load regime, was reduction of NOx emission.

The findings of this study are summarized below:

1. The intake pressure does not influence thermal efficiency of the engine, however considering of compression work makes the boost application negative from the energetic point of view. The use of turbocharger in a multi-cylinder engine would make the charging process advantageous, as turbine backpressure could be compensated by increase of exhaust valve effective flow area.

2. Increase of intake pressure results in increase of PRR due to auto-ignition advance.

3. Increase of fuel dilution ratio obtained by boost application results in considerable drop of cylinder-out $\mathrm{NO}_{\mathrm{x}}$ emission. However, in the range of low loads it is associated with some penalty in terms of larger $\mathrm{CO}$ emission.

\section{Acknowledgements}

The authors wish to thank AVL List GmbH for making simulation software available within a framework of AVL University Partnership Program.

\section{Nomenclature/oznaczenia \\ CA/OWK Crankshaft Angle/kąt obrotu watu korbowego \\ EGR Exhaust Gas Re-circulation/recyrkulacja spalin \\ EVC/ZW Exhaust Valve Closing/zamknięcie zaworu wyloto- wego \\ EVO/OW Exhaust Valve Opening/otwarcie zaworu wylotowego \\ FTIR Fourier Transform Infrared/transformata Fouriera widma w podczerwieni \\ HRR Heat Release Rate/szybkość wywiąywania się ciepla \\ IMEP/pi Indicated Mean Effective Pressure/średnie ciśnienie indykowane \\ IVC/ZD Intake Valve Closing/zamknięcie zaworu dolotowego \\ IVO/OD Intake Valve Opening/otwarcie zaworu dolotowego \\ $\lambda \quad$ Air Excess Ratio/wspótczynnik nadmiaru powietrza \\ MFB Mass Fraction Burnt/stopień wypalenia dawki paliwa \\ NVO/UWZ Negative Valve Overlap/ujemne współotwarcie za- worów \\ PRR Pressure Rise Rate/szybkość narastania ciśnienia}

Jacek Hunicz, DSc., DEng. - doctor in the Faculty of Mechanical Engineering at Lublin University of Technology.

Dr hab. inż. Jacek Hunicz - adiunkt na Wydziale Mechanicznym Politechniki Lubelskiej. e-mail:j.hunicz@pollub.pl

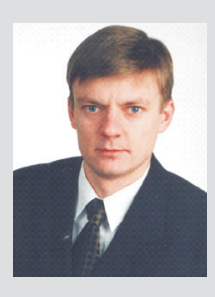

Michał Gęca, MEng. - post-graduated student in the Faculty of Mechanical Engineering at Lublin University of Technology.

Mgr inż. Michat Gęca - doktorant na Wydziale Mechanicznym Politechniki Lubelskiej.

e-mail: michal.geca@pollub.pl

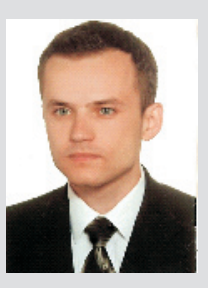

3.Zwiększenie ilości powietrza w cylindrze znacznie obniża emisję tlenków azotu, prowadząc w przypadku małych obciążeń do niewielkiego wzrostu emisji tlenku węgla.

\section{Podziękowania}

Autorzy dziękują firmie AVL List GmbH za udostępnienie oprogramowania symulacyjnego Advanced Smulation Technologies w ramach programu AVL University Partnership.

\section{Paper reviewed/Artykut recenzowany}

\section{Bibliography/Literatura}

[1] Blaxill H., Cairns A.: Production-feasible controlled autoignition, Auto Technology, vol. 7, pp. 28-31, 2007.

[2] Gaynor J.A., Fleck R., Kee R.J., Kenny R.G., Cathcart G.: A study of efficiency and emissions for a 4-Stroke SI and a CAI engine with EEGR and light boost, SAE Technical Paper 2006-32-0042, 2006.

[3] Hunicz J.: Kontrolowany samozapłon w silniku benzynowym, Wydawnictwo Politechniki Lubelskiej, 2011.

[4] Hunicz J., Kordos P.: Experimental study of the gasoline engine operated in spark ignition and controlled auto-ignition combustion modes, SAE Technical Paper 2009-01-2667, 2009.

[5] Kozaczewski W.: Zmienne fazy rozrządu - nowe rozwiązania i silnik badawczy do badania ich wpływu, Journal of KONES Combustion Engines, vol. 8, No 3-4, pp. 182-187, 2001.

[6] Lavy. J., Dabadie J.Ch., Angelberger Ch., Duret P., Willand J., Juretzka A., Schäflein J., Ma T., Lendresse Y., Satre A., Schulz Ch., Kraämer H., Zhao H., Damiano L.: Innovative ultra-low NOX controlled auto-ignition combustion process for gasoline engines: the 4-SPACE project, SAE Technical Paper 2000-01-1837, 2000.

[7] Najt P., Foster D.E.: "Compression-Ignited Homogeneous Charge Combustion", SAE Technical Paper 830264, 1983.

[8] Noguchi M., Tanaka Y., Tanaka T., Takeuchi Y.: A Study on Gasoline Engine Combustion by Observation of Intermediate Reactive Products during Combustion, SAE Technical paper 790840, 1979.

[9] Scaringe R.J., Wildman C., Cheng W.K.: On the high load limit of boosted gasoline HCCI engine operating in NVO mode, SAE Technical Paper 2010-01-0162, 2010.

[10] Stanglmaier R.H., Roberts Ch.E.: Homogeneous charge compression ignition (HCCI): benefits, compromises, and future engine applications, SAE Technical Paper 1999-01-3682, 1999.

[11] Urushihara T., Hiraya K., Kakuhou A., Itoh T.: Expansion of HCCI operating region by the combination of direct fuel injection, negative valve overlap and internal fuel reformation, SAE Technical Paper 2003-01-0749, 2003.

[12] Wildman C., Scaringe R.J., Cheng W.K.: On the maximum pressure rise rate in boosted HCCI operation, SAE Technical Paper 2009-01-2727, 2009.

[13] Yao M., Zheng Z., Liu H.: Progress and recent trends in homogeneous charge compression ignition (HCCI) engines, Progress in Energy and Combustion Science, vol. 35, pp. 398-437, 2009.

[14] Yap D., Wyszyński M.L., Megaritis A., Xu H.: Applying boosting to gasoline HCCI operation with residual gas trapping, SAE Technical Paper 2005-01-2121, 2005. 